\title{
Long-Term Consequences of Neonatal Rearing on Central Corticotropin-Releasing Factor Systems in Adult Male Rat Offspring
}

\author{
Paul M Plotsky*,', KV Thrivikraman', Charles B Nemeroff ${ }^{2}$, Christian Caldji ${ }^{3}$, Shakti Sharma ${ }^{3}$ and \\ Michael J Meaney ${ }^{3}$ \\ 'Stress Neurobiology Laboratory, Department of Psychiatry and Behavioral Sciences, Emory University, Atlanta, GA, USA; ${ }^{2}$ Laboratory of \\ Neuropsychopharmacology, Department of Psychiatry and Behavioral Sciences, Emory University, Atlanta, GA, USA; ${ }^{3}$ Developmental \\ Neuroendocrinology Laboratory, Departments of Psychiatry, and Neurology and Neurosurgery, Douglas Hospital Research Centre, \\ McGill University, Montreal, QC, Canada
}

In a series of studies on the long-term consequences of neonatal rearing, we compared hypothalamic and extrahypothalamic central corticotropin-releasing factor (CRF) systems in male rats reared under conditions of animal facility rearing, nonhandling (HMSO), handling with brief maternal separation for 15 min (HMSI5), or handling with moderate maternal separation for 180 min (HMSI80) daily from postnatal days 2-14. CRF-like immunoreactivity (CRFir) was elevated in lumbar cerebrospinal fluid of adult HMSI 80 and HMSO rats relative to the other groups. In the paraventricular nucleus, central nucleus of the amygdala, bed nucleus of the stria terminalis, and locus coeruleus, CRFir and CRF mRNA levels were significantly elevated in HMSO and HMSI80 rats. Neonatal maternal separation was associated with regionally specific alterations in CRF receptor type I (CRFI) mRNA density in HMSI 80 rats. No rearing-associated differences in CRF2 $\alpha$ binding were apparent in either the lateral septum or the ventromedial hypothalamus. These findings indicate that early rearing conditions can permanently alter the developmental set-point of central CRF systems, and potentially influence the expression of behavioral and endocrine responses to stress throughout life, thereby providing a possible neurobiological substrate for the relationship between early life events and increased vulnerability for hypothalamic-pituitary-adrenal axis and coping skill alterations and the frequency of mood disorders in patients with a history of such experiences.

Neuropsychopharmacology (2005) 30, 2192-2204. doi:I0. I038/sj.npp. I 300769; published online 25 May 2005

Keywords: maternal separation; stress; corticotropin-releasing factor receptors; cerebrospinal fluid; paraventricular nucleus; locus coeruleus

\section{INTRODUCTION}

The nature of the early postnatal environment can stably alter behavioral and hypothalamic-pituitary-adrenal (HPA) axis responses to stressors in the rat (Denenberg, 1964; Levine, 1975; Bhatnagar et al, 1995; Meaney et al, 1996; Liu et al, 1997; Ladd et al, 1996, 2000), although the mechanisms underlying these effects remain unclear. Most notable among these behavioral effects are changes in responses to novelty. In response to a number of testing conditions, adult offspring reared under conditions of

*Correspondence: Professor PM Plotsky, Department of Psychiatry \& Behavioral Sciences, Emory University School of Medicine, 1639 Pierce Drive, Suite 4000, Atlanta, GA 30322, USA, Tel: + I 404727 8258, Fax: + I 404727 3233, E-mail: pplotsky@emory.edu

Received 14 December 2004; revised 31 March 2005; accepted 8 April 2005

Online publication: 13 April 2005 at http://www.acnp.org/citations/ NPP04 I $305040587 /$ default.pdf neonatal maternal separation show increases, while neonatal handling exhibits decreases in behavioral fearfulness when compared to animals that were unhandled during the neonatal period (Caldji et al, 2000). Similarly, HPA axis responsivity to stressors is enhanced in animals exposed as neonates to repeated daily maternal separation for $\geqslant 180 \mathrm{~min}$ as compared to unhandled (Viau et al, 1993; Ladd et al, 1996) or animal facility reared rats (Ladd et al, 2000; Huot et al, 2001). These behavioral and endocrine responses to novelty may either be under independent control or tightly linked via alterations in novelty or stressor-sensitive neurocircuits.

Central corticotropin-releasing factor (CRF) systems have been strongly implicated in the expression of behavioral responses to stressors as well as in the regulation of HPA axis responsivity. Intracerebroventricular administration of CRF produces responses comparable to those of fearinducing stimuli (Dunn and Berridge, 1990; Owens and Nemeroff, 1991) including increased locomotor activity in a 
familiar environment (reviewed in Koob et al, 1994), suppressed exploration in a novel environment (Britton et al, 1982; Sutton et al, 1982; Berridge and Dunn, 1987; Takahashi et al, 1989), enhanced stress-induced freezing (Sherman and Kalin, 1988) and grooming (Britton et al, 1984; Imaki et al, 1987), decreased sexual behavior (Sirinathsinghji et al, 1983), facilitation of acoustic startle (Swerdlow et al, 1986; Liang et al, 1992a,b), and decreased food intake (Krahn et al, 1986; Arase et al, 1988). These effects are blocked by administration of the CRF receptor antagonist $\alpha$-helical CRF (Dunn and Berridge, 1990; Menzaghi et al, 1993). In addition, CRF administration has aversive properties, producing both taste and place aversions (Cador et al, 1992; Heinrichs et al, 1992a, 1993). Koob (1999) has proposed the existence of a feed-forward system between norepinephrine (NE) and CRF systems to coordinate the response to environmental challenges. Considerable pharmacologic, physiologic, and neuroanatomical evidence supports a CRF-NE interaction in the region of the locus coeruleus (Koob, 1999; Lejeune and Millan, 2003; Page and Valentino, 1994; Plotsky et al, 1989; Valentino et al, 1998).

Further evidence for the importance of the central CRF system is derived from studies of a transgenic CRF overexpression mouse model (Stenzel-Poore et al, 1994). These animals exhibit enhanced stress-induced suppression of exploration that can be reversed with intracerebroventricular administration of the CRF receptor antagonist $\alpha$ helical $\mathrm{CRF}_{9-41}$. These findings are consistent with the thesis that CRF overproduction contributes to the etiology and/or pathophysiology of mood disorders (Chrousos and Gold, 1992; Arborelius et al, 1999).

The effects of CRF on the expression of behavioral, endocrine, and autonomic responses to stress appear to be attributable to two major CRF systems: (a) the hypothalamic paraventricular nucleus (PVN) CRF neuronal system, which projects to the median eminence thus regulating adenohypophysial adrenocorticotropin (ACTH) secretion as well as to midbrain regions regulating sympathetic activity, and (b) CRF neurons in the central nucleus of the amygdala (CeA) and the bed nucleus of the stria terminalis (BNST), regions projecting to the $\mathrm{PVN}$ as well as to midbrain regions rich in noradrenergic cell bodies (Brown, 1989; Plotsky, 1991; Gray, 1993; Koob, 1999; Van Bockstaele et al, 2001).

Hofer (1994) has offered the concept that the mother or primary caregiver acts as a hidden regulator of the development of infant physiological regulatory systems. Thus, a further impetus for this research is the growing evidence for a link between early untoward life experiences, such as neglect or abuse, and increased vulnerability to HPA axis alterations and psychiatric diseases such as depression (Heim and Nemeroff, 2001; Heim et al, 2002, 2004). Accumulating data demonstrate increased neural CRF expression (Raadsheer et al, 1994, 1995) and hypersecretion (Banki et al, 1987; De Bellis et al, 1993; Geracioti et al, 1992; Nemeroff et al, 1991) in some, but not all, patients with major depressive disorder. Many of these patients have a history of exposure to untoward life events occurring prior to their teenage years and often continuing into adulthood (Brown and Anderson, 1993; Mullen et al, 1996; McCauley et al, 1997; Heim et al, 2000; Kendler et al, 2002). This raises the question of whether early life trauma, rather than depression per se, is associated with dysregulation of central CRF systems, which then results in secondary depression. In light of the pervasive effects of CRF on the organization of emotion and responses to stressors (Owens and Nemeroff, 1991; Koob et al, 1994), we have examined the status of hypothalamic and extrahypothalamic CRF neurocircuits in adult rats exposed as neonates to different rearing protocols associated with alterations in HPA axis function and behavioral responsivity.

\section{MATERIALS AND METHODS}

\section{Animals}

Timed-pregnant Long Evans hooded rats were delivered on gestation day 12 to Emory University from Charles River (Crl:(LE)BR; Charles River Laboratories, Portage, MI). Studies at McGill University were performed with rats obtained from an 'in-house' breeding colony derived from Charles River Laboratory Long Evans rats. All dams were housed in transparent, polypropylene cages $(20 \times 25 \mathrm{~cm})$ with $2 \mathrm{~cm}$ bedding material and ad libitum access to food and water in a room with a $12: 12 \mathrm{~h}$ light: dark cycle (lights on at 0700 ). The day of birth was considered postnatal day (PND) 0. Litters were standardized to 8-10 male pups per dam on PND2 and were exposed to one of the following rearing conditions from PND2 to PND14 inclusive: (a) animal facility rearing (AFR) consisted of brief handling for twice weekly cage changes beginning on PND4 with no other handling or separation, (b) nonhandled (HMS0) animals were not exposed to any handling or experimenter manipulation, including cage bedding changes, from PND2 to PND14, (c) handling with brief maternal separation for 15 min (HMS15) from PND2 to PND14, and (d) handling with moderate maternal separation for $180 \mathrm{~min}$ (HMS180) from PND2 to PND14. The HMS protocol was initiated in the morning between 0800 and 0900 by a gloved investigator. Each dam was removed from the home cage to an adjacent cage, then each litter was removed and placed as a group into a plastic cage $(15 \times 15 \mathrm{~cm})$ that was transferred to an incubator in an adjacent room. These pup cages were lined with $3 \mathrm{~cm}$ of bedding material (wood shavings) and were placed into an incubator set to maintain an ambient temperature of $32+0.5^{\circ} \mathrm{C}$ (PND2-5) or $30+0.5^{\circ} \mathrm{C}$ (PND614). At the conclusion of the separation period, pups were returned to the maternity cage, rolled in the soiled home cage bedding material, and the dam was returned. In the course of normal mother-pup interactions in the laboratory rat, the mother is routinely off the litter for periods of 20-25 min (Jans and Woodside, 1990). Thus, the maternal separation protocol (HMS180), unlike handling and brief maternal separation (HMS15), represents deprivation of maternal care. Unless otherwise noted, the bedding material in all of the cages (eg maternity, transfer, pup isolation) was not changed from PND0 to at least PND15. According to Champagne et al (2003), gender composition of the litter does not significantly influence the frequency of maternal licking, grooming, or arched-back nursing and, thus, has little effect with respect to outcome measures of HPA development or CNS expression levels of stress-related genes. This is not to deny that specific aspects of maternal behavior toward male and female pups differ (Moore and 
Morelli, 1979; Pryce et al, 2001). Rat pups were weaned on PND21-22 and housed in groups of 2-4 same rearing group animals per cage until testing. Food and water was available ad libitum. All experiments were carried out in accordance with the National Institutes of Health Guide for the Care and Use of Laboratory Animals.

\section{Blood Sampling and Airpuff Startle}

Adults were tested for HPA axis responsiveness using airpuff startle on PND60-75. Jugular cannulae were implanted as previously described to allow for repeated sampling in freely moving animals (Thrivikraman et al, 2000), and a 4-day recovery period, during which time the rats were handled daily, was permitted before testing.

The blood sampling protocol began between 0900 and 1000 with airpuff startle initiated after obtaining a basal sample. Airpuff startle consisted of three blocks of three airpuffs each (3 s) from a compressed air source (Dust-Off; Fisher Scientific, Atlanta, GA) that was directed toward the side of the head from a distance of approximately $10 \mathrm{~cm}$, with $1 \mathrm{~min}$ between each block (Engelmann et al, 1996). Blood $(300 \mu \mathrm{l} / \mathrm{sample})$ was collected through the jugular cannula into $1.5 \mathrm{ml}$ polyethylene tubes containing $10 \mu \mathrm{l}$ EDTA $(100 \mathrm{mg} / \mathrm{ml})$ at rest and at 5, 10, 15, 30, 45, and $60 \mathrm{~min}$ following airpuff startle. Blood samples were stored on ice, then centrifuged $\left(12500 \mathrm{~g} ; 4^{\circ} \mathrm{C} ; 12 \mathrm{~min}\right)$, plasma collected and frozen.

\section{ACTH and Corticosterone Radioimmunoassay Analysis}

Plasma ACTH and corticosterone (CORT) were assayed as previously described (Thrivikraman and Plotsky, 1993). For ACTH, $100 \mu \mathrm{l}$ plasma samples were used for the Allegro ${ }^{\mathrm{TM}}$ HS-ACTH kit (Nichols Institute, San Juan Capistrano, CA) with $50 \mu \mathrm{l}$ of iodonated tracer and one avidin-coated bead per tube. The ACTH assay had a sensitivity of $2 \mathrm{pg} / \mathrm{ml}$ and intra- and intercoefficients of variation of less than $10 \%$. CORT was determined in $5 \mu$ l plasma samples using the ImmunoChem $^{\mathrm{TM}}$ Double Antibody kit (ICN Biomedicals, Costa Mesa, CA) with half of the trace and antibody volume. The CORT assay had a sensitivity of $1 \mathrm{ng} / \mathrm{ml}$ and intra- and inter coefficients of variation of less than $10 \%$.

\section{Lumbar Cerebrospinal Fluid Sampling}

Intrathecal catheters were constructed of 32 ga polyurethane tubing (Micor, Allison Park, PA) of approximately $10.7 \mathrm{~cm}$ length as described by Sakura et al (1996). A $5 \mathrm{~mm}$ long stainless-steel tubing segment ( $27 \mathrm{ga})$ was fitted to a heatflared segment of the polyurethane tubing. This assembly was cold sterilized and then a sterilized Teflon-coated stainless-steel wire stylet (0.003 in diameter) was inserted into the polyurethane catheter prior to placement.

The catheter was placed according to a modification of the technique described by Yaksh and Rudy (1976). Rats ( $n=10$ per rearing group) drawn from the same litters as animals in the other experiments were anesthetized as described above, then the back of the head and neck shaved, and disinfected with alcohol (70\%). The rat was then placed in a stereotaxic headholder with the head flexed forward. A midline incision was made on the back of the neck. The muscle was freed from the skull and retracted to reveal the cisternal membrane. This membrane was opened with a microknife and retracted with a dural microhook. The sterile catheter was inserted through this defect and gently passed caudally approximately $9 \mathrm{~cm}$ into the intrathecal space so that the tip rested in the Th11-L5 region. The dural defect was repaired with tissue glue (Vet-Bond; Henry Schein, Port Washington, NY) and a small piece of GelFoam. The cannula was anchored to the skull using jeweler's screws and cranioplastic cement and the skin incision was closed with stainless-steel wound clips. A recovery period of 5 days was permitted prior to sampling. Each rat was handled on a daily basis.

For sampling, the catheter was attached to a silastic extension line connected to a microsyringe pump (CMA Systems, Stockholm, Sweden). Cerebrospinal fluid (CSF) was withdrawn at the rate of $500 \mathrm{nl} / \mathrm{min}$ for $4 \mathrm{~h}$ into a replaceable loop of Teflon tubing immersed into an icebath. Upon completion of each collection, the CSF was expelled into a cold $500 \mathrm{nl}$ centrifuge tube containing $1 \mu \mathrm{l}$ EDTA $(100 \mathrm{mg} / \mathrm{ml})$ and frozen at $-80^{\circ} \mathrm{C}$ until assay.

\section{Tissue Collection}

Adult animals were killed by decapitation between 0900 and 1200 under low stress conditions when they were between PND100 and PND120. The skull was quickly opened, the brain removed, then rinsed and chilled in sterile saline on ice. Each brain was blocked $(\sim 300 \mu \mathrm{m})$ in a coronal brain matrix (Bioanalytical Systems, West Lafayette, IN). The tissue slabs were placed on a glass plate on ice, then individual regions were obtained using 1 or $2 \mathrm{~mm}$ diameter stainless-steel punches according to the procedure of Palkovits and Brownstein (1988). Each punch was snapfrozen on dry ice and stored in $1.5 \mathrm{ml}$ polyethylene microcentrifuge tube at $-80^{\circ} \mathrm{C}$ until assay. Tissues from five to eight rats per group were collected for analysis.

\section{CRF Radioimmunoassay}

Tissue CRF-like immunoreactivity (CRFir) levels were determined using a modified version of the radioimmunoassay described by Plotsky et al (1985). Tissue punches homogenized by sonication in a solution composed $0.1 \mathrm{~N}$ $\mathrm{HCl}$ containing $0.001 \% \beta$-mercaptoethanol, $0.05 \%$ ascorbic acid, $0.01 \%$ bacitran, and $0.001 \%$ phenylmethylsulfonyl fluoride. Samples were centrifuged at $12000 \mathrm{~g}$ for $30 \mathrm{~min}$ at $4{ }^{\circ} \mathrm{C}$. The supernatant was removed, lyophilized, and frozen until assay. Samples were reconstituted in pH 7.0 phosphate buffer containing $0.1 \%$ bovine serum albumin (BSA) fraction-V, $0.1 \%$ Triton-X, and $0.01 \%$ sodium azide.

Antiserum rC70 (provided by W Vale, The Salk Institute, La Jolla, CA) was used at a final dilution of 1:500000. Synthetic rat $\mathrm{CRF}_{1-41}$ (provided by J Rivier, The Salk Institute, La Jolla, CA) was used for assay standard and $\left[{ }^{125} \mathrm{I}\right]$ Tyr-ovine CRF (DuPont-NEN, Boston, MA) was used for tracer. The limit of detection was $2 \mathrm{pg} / \mathrm{tube}$ with an $\mathrm{IC}_{50}$ of $22 \mathrm{pg}$. The intra-assay coefficient of variation was $3.6 \%$. Note that all tissue samples were run in the same assay. 


\section{In Situ Hybridization}

Rats (PND100-120) were deeply anesthetized (0800-1200), decapitated, and brains removed and stored at $-80^{\circ} \mathrm{C}$. Serial coronal brain sections $(15 \mu \mathrm{m})$ were cut on a cryostat at $-18^{\circ} \mathrm{C}$ and thaw mounted onto SuperFrost Plus slides (Fisher Scientific, Atlanta, GA) under RNase-free conditions and stored with Humi-Cap desiccant capsules (Gibco BRL Products, Grand Island, NY) at $-80^{\circ} \mathrm{C}$ until assay. In situ hybridization was performed according to the procedures described by Simmons et al (1989). Briefly, slides were warmed in a stepwise manner to room temperature, postfixed in $4 \%$ paraformaldehyde ( $\mathrm{pH} \mathrm{7.4)} \mathrm{for} 20 \mathrm{~min}$, and rinsed twice in $10 \mathrm{mM}$ phosphate-buffered saline (PBS, $\mathrm{pH}$ 7.4) for $2 \mathrm{~min}$. Next, the slides were treated for $15 \mathrm{~min}$ with proteinase $\mathrm{K}$ (Promega, Madison, WI) $10 \mu \mathrm{g} / \mathrm{ml}$ in $0.1 \mathrm{M}$ Tris with $50 \mathrm{mM}$ EDTA followed by acetylation (10 min, $0.5 \%$ acetic anhydride in $0.1 \mathrm{M}$ triethanolamine, $\mathrm{pH}$ 8.0), two rinses in $2 \times \mathrm{SSC}$, and dehydrations through a graded ethanol series. The sections were then air-dried for at least $1 \mathrm{~h}$ prior to hybridization.

The CRF riboprobe was constructed from a $1.2 \mathrm{~kb} E c o$ RI fragment of a full-length rat CRF cDNA (provided by $\mathrm{K}$ Mayo, Northwestern University, Evanston, IL) subcloned into a pBluescript II-SK + plasmid. The CRF1 riboprobe was constructed from a $1.3 \mathrm{~kb}$ PstI-PstI fragment containing the full-length coding region for the rat CRF1 receptor (provided by $\mathrm{W}$ Vale, The Salk Institute, La Jolla, CA), ligated into a pBluescript II-SK + plasmid. The CRF $2 \alpha$ riboprobe was constructed from a $275 \mathrm{bp}$ fragment, encoding the $\mathrm{N}$-terminal region of the CRF2 $\alpha$ receptor, ligated into a pBluescript II-SK + plasmid (provided by W Vale, The Salk Institute, La Jolla, CA). Radiolabeled antisense CRNAs were synthesized by incorporating either $\left[{ }^{35} \mathrm{~S}\right] \mathrm{UTP}$ (DuPont-NEN) into the CRF probe or $\left[{ }^{35} \mathrm{~S}\right] \mathrm{CTP}$ plus $\left[{ }^{35} \mathrm{~S}\right] \mathrm{UTP}$ into the CRF1 and CRF2 receptor probes. The transcription reactions were performed utilizing the Ambion MAXIscript kit (Austin, TX) with SP6 (CRF), T7 (CRF1), or T3 (CRF2) RNA polymerases according to the instructions provided. Following transcription and removal of the cDNA template with $2 \mathrm{U}$ DNase (Ambion), the cRNA probes were recovered through ethanol precipitation and/or gel filtration using a G-50 Sephadex Quick Spin column (Boehringer-Mannheim, Indianapolis, IN).

The brain sections were hybridized overnight at $58-60^{\circ} \mathrm{C}$ with $2 \times 10^{6} \mathrm{cpm}$ of ${ }^{35} \mathrm{~S}$-labeled cRNA probe diluted into hybridization buffer ( $50 \%$ formamide, $10 \%$ dextran sulfate, $0.3 \mathrm{M} \mathrm{NaCl}, 1 \times$ Denhardt's solution, $10 \mathrm{mM}$ Tris, $1 \mathrm{mM}$ EDTA, $2 \mathrm{mg} / \mathrm{ml}$ yeast tRNA, $10 \mathrm{mM}$ DTT) in humidified Nunc trays (Nalge Nunc Inc., Naperville, IL). The next day, slides were allowed to cool to room temperature before being washed four times in $4 \times$ SSC for 5 min on a rotating platform at $60 \mathrm{rpm}$. The sections were then treated with $250 \mu \mathrm{g} / \mathrm{ml}$ RNase A (Promega, Madison, WI) for $30 \mathrm{~min}$ at $37^{\circ} \mathrm{C}$. Subsequently, the slides underwent a series of SSC washes (supplemented with $1 \mathrm{mM}$ DTT) with salt concentrations decreasing from $2 \times$ to $0.5 \times$, followed by a $60 \mathrm{~min}$ high-stringency wash with $0.1 \times \mathrm{SSC}+1 \mathrm{mM} \mathrm{DTT}$ at $60^{\circ} \mathrm{C}$, then dehydration through a graded ethanol series. The slides were air-dried for at least $1 \mathrm{~h}$ and then apposed to Kodak Biomax MR film (Rochester, NY) for $12 \mathrm{~h}$ to 12 days depending on the probe and brain region examined with ${ }^{14} \mathrm{C}$ standards (Amersham, Piscataway, NJ). Controls were performed to establish specificity of the signal included hybridization with sense strand probes, as well as predigestion with RNase A.

\section{CRF Receptor Autoradiography}

Following a modification of the techniques of De Souza et al (1985), De Souza (1987), and Primus et al (1997), in vitro CRF receptor autoradiography was performed on $15 \mu \mathrm{m}$ rat brain sections mounted on SuperFrost Plus slides. Sections were fixed for $2 \mathrm{~min}$ in $0.1 \%$ paraformaldehyde followed by $15 \mathrm{~min}$ incubation in assay buffer $(50 \mathrm{mM}$ Tris, $10 \mathrm{mM}$ $\mathrm{MgCl}_{2}, 2 \mathrm{mM}$ EGTA, $0.1 \%$ BSA, $0.1 \mathrm{mM}$ bacitracin, and $0.1 \%$ aprotinin; $\mathrm{pH}$ 7.5) to remove endogenous CRF. Triplicate slides containing adjacent brain sections were incubated for $2 \mathrm{~h}$ at room temperature in one of three conditions: (a) $0.1 \mathrm{nM}$ radiolabeled $\left[{ }^{125} \mathrm{I}\right]$ sauvagine (DuPont-NEN) to determine total binding at both the CRF1 and CRF2 receptor subtypes, (b) $0.1 \mathrm{nM}$ radiolabeled $\left[{ }^{125} \mathrm{I}\right]$ sauvagine $+1 \mu \mathrm{M}$ CP-154,526 (CRF1 antagonist provided by Pfizer Inc., Groton, CT) to determine CRF $2 \alpha$ receptor-specific binding, or (c) $0.1 \mathrm{nM}$ radiolabeled $\left[{ }^{125} \mathrm{I}\right]$ sauvagine $+1 \mu \mathrm{M}$ unlabeled sauvagine (American Peptide Company, Sunnyvale, $\mathrm{CA}$ ) to determine nonspecific binding. Following the incubation, unbound radioligand was removed by two 5 min rinses in ice-cold $\left(4^{\circ} \mathrm{C}\right) \mathrm{PBS}+1 \% \mathrm{BSA}$ on a rotating platform at $60 \mathrm{rpm}$, followed by two brief dips in ice-cold $\mathrm{ddH}_{2} \mathrm{O}$. Slides were then rapidly dried and apposed to Kodak Biomax MR film (Rochester, NY) with ${ }^{125} \mathrm{I}$-microscale standards (Amersham, Piscataway, NJ) for 80-90 h.

\section{Image Analysis}

Images from the in situ hybridization and receptor autoradiography films were digitized using a Dage-MTI CCD72 camera (Sony Corp., Tokyo, Japan) and images were captured using a Frame Grabber card (Data Translation, S Natick, MA) equipped Quadra 950 computer. Semiquantitative analysis was performed using NIH Image (Wayne Rasband, NIH, Bethesda, MD). Optical densities were calibrated against ${ }^{14} \mathrm{C}$ standards (in situ hybridization films) or ${ }^{125}$ I-microscale standards (receptor autoradiography films) and expressed in terms of $\mathrm{nCi} / \mathrm{g}$ tissue equivalent. For the purpose of quantifying mRNA levels, specific signal was determined as the optical density of the region examined minus the optical density of neutral background present in the same brain section. For the purpose of quantifying CRF receptor level, CRF1 receptorspecific binding was calculated as total binding minus CRF2 receptor-specific binding, while CRF2 receptor-specific binding was calculated as CRF2 receptor-specific binding minus nonspecific binding. In all cases, 3-5 sections per region were matched for rostrocaudal level according to the atlas of Paxinos and Watson (1986) and used to produce a single value for each animal. Sections from five to eight rats per group were used for statistical analysis.

\section{Statistical Analysis}

Statistical comparisons were performed using the ANOVA with Tukey-Kramer multicomparison post hoc tests using 
InStat 3 and Prism 4 (GraphPad Software, San Diego, CA). Data are presented as mean + SEM.

\section{RESULTS}

\section{Basal and Stress-Induced ACTH and CORT}

Basal plasma ACTH levels were similar among the rearing groups (AFR $19.94 \pm 1.27 \mathrm{pg} / \mathrm{ml}$; HMS0 19.33 \pm 1.72 ; HMS15 $18.74 \pm 1.21$; HMS180 19.18 \pm 1.93$)$. As shown in Figure 1a, presentation of an acute APS stressor was associated with a significant rearing-associated $\left(\mathrm{F}_{3,216}=69.51, p<0.0001\right)$ elevation in ACTH over time $\left(\mathrm{F}_{6,216}=586.60, p<0.0001\right)$ as determined by ANOVA corrected for repeated measures. In all four groups, acute APS caused a marked increase in mean plasma ACTH concentration, peaking at $10 \mathrm{~min}$ and returning toward baseline by $60 \mathrm{~min}$ poststress. The plasma ACTH peak was approximately 1.6 -fold greater $(p<0.001)$ in HMS180 rats $(263 \pm 19 \mathrm{pg} / \mathrm{ml})$ as compared to either HMS15 or AFR rats $(148 \pm 15$ vs $165 \pm 15 \mathrm{pg} / \mathrm{ml}$, respec-
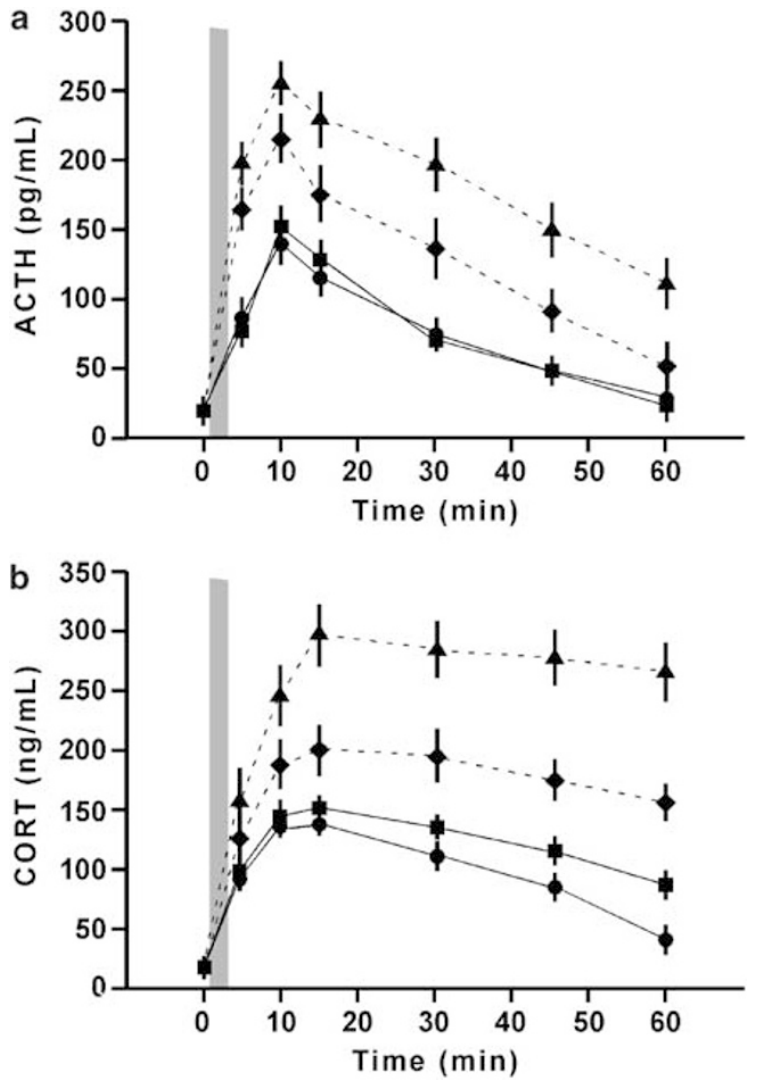

Figure I Effect of rearing condition on adult pituitary-adrenal responses to airpuff startle (APS). There were no rearing-associated differences in basal trough plasma ACTH (a) or CORT (b) levels. However, the response to airpuff startle (APS; denoted by gray area) showed a significant rearing effect for both ACTH $\left(F_{3}, 216=69.5 \mathrm{I}, p<0.000 \mathrm{I}\right)$ and CORT $\left(F_{3}\right.$, $216=37.65, \quad p<0.0001)$. Animal facility reared (AFR; squares) and handling-maternal separation 15 (HMSI5; circles) groups were not significantly different from one another. However, both of these groups exhibited smaller responses than did the handling-maternal separation 0 (HMSO or nonhandled; diamonds) or handling-maternal separation 180 (HMS 180; triangles) groups. Each group consisted of 10 adult animals (PND75-90) selected from at least eight different litters. Data represent mean \pm SEM. See text for additional details. tively), which were not significantly different from one another. Peak ACTH levels in the HMS0 rats $(219 \pm 16 \mathrm{pg} /$ $\mathrm{ml})$ were significantly less $(p<0.001)$ than that observed in HMS180 rats, but significantly different from either HMS15 or AFR rats $(p<0.001)$.

Two-way ANOVA with repeated measures on time revealed significant effects for rearing $\left(\mathrm{F}_{3,216}=49.85\right.$, $p<0.0001)$ and time $\left(\mathrm{F}_{6,216}=127.11, p<0.0001\right)$ on plasma CORT levels following an acute APS stressor (Figure 1b). However, no rearing-associated differences in basal trough CORT levels were observed. Plasma CORT levels peaked $15 \mathrm{~min}$ after initiation of APS in all of the groups. Peak levels at $15 \mathrm{~min}$ were not significantly different between AFR $(143 \pm 16 \mathrm{ng} / \mathrm{ml})$ and HMS15 $(137 \pm 14 \mathrm{ng} / \mathrm{ml})$ rats. Peak levels for HMS0 $(203 \pm 20 \mathrm{ng} / \mathrm{ml})$ and HMS180 $(300 \pm 26 \mathrm{ng} /$ $\mathrm{ml})$ rats were significantly different $(p<0.01)$ from one another and from AFR and HMS15 rats $(p<0.001)$. While CORT returned toward initial levels in the AFR and HMS15 groups, it remained significantly elevated in the HMSO and HMS180 groups.

\section{Lumbar CSF CRFir}

The distribution of morning CSF CRFir levels is shown in Figure 2. One-way ANOVA revealed a significant effect of rearing $\left(\mathrm{F}_{3,36}=15.19, p<0.001\right)$ on CSF CRF. Levels $($ mean \pm SEM $)$ of the AFR $(37 \pm 3 \mathrm{pg} / \mathrm{ml})$ and HMS15 $(36 \pm 2 \mathrm{pg} / \mathrm{ml})$ groups were not significantly different from one another, but were greater than that of either the HMS0 $(53 \pm 4 \mathrm{pg} / \mathrm{ml})$ or HMS180 $(68 \pm 6 \mathrm{pg} / \mathrm{ml})$ groups.

\section{CRF mRNA Expression}

As illustrated in Figure 3, densitometry of X-ray films showed significant rearing-associated differences in the

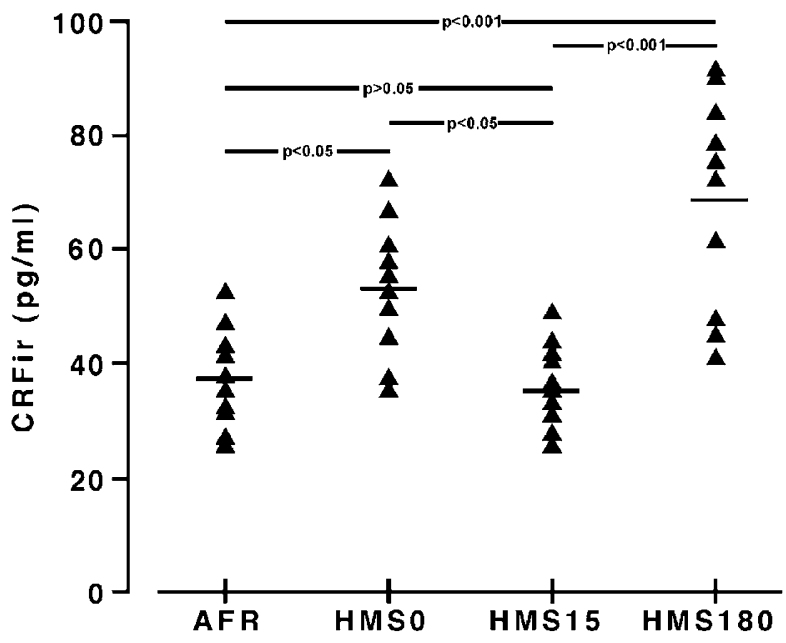

Figure 2 Lumbar CSF CRFir levels. Adult animals of the four rearing groups ( $n=10 /$ group) were each instrumented with an indwelling intrathecal lumbar cannula (see text for details). After a 5-day recovery period, unanesthetized animals were sampled at the rate of $500 \mathrm{nl} / \mathrm{min}$ for $4 \mathrm{~h}$ beginning at 0800. Samples were radioimmunoassayed for CRFir. ANOVA confirmed a rearing effect $(p<0.00 \mathrm{I})$. Post hoc statistical comparisons by Tukey-Kramer are shown. AFR: animal facility reared; HMSO: handling-maternal separation 0 min or nonhandled; HMSI5: handling-maternal separation 15 min; HMSI80: handling-maternal separation $180 \mathrm{~min}$. 


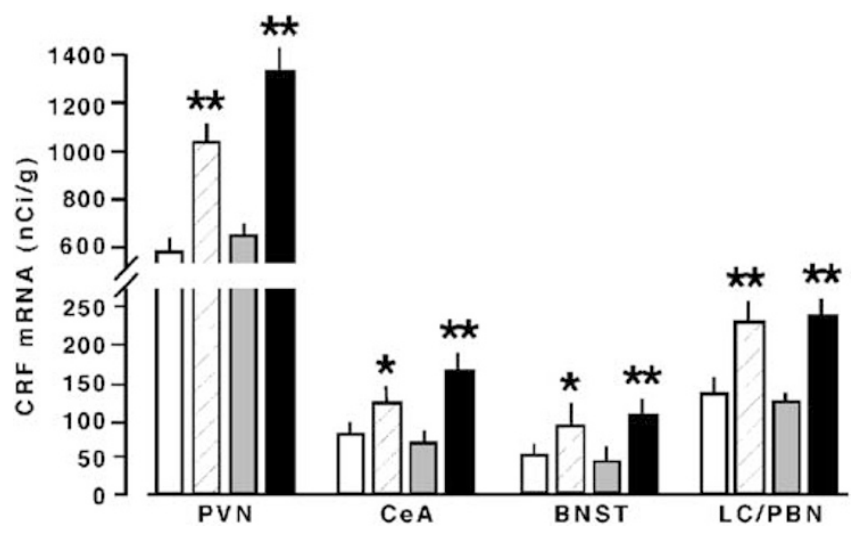

Figure 3 Densitometric analysis of CRF mRNA levels in the PVN, CeA, BNST, and LC/PBN of adult animals reared under conditions of common animal facility rearing (AFR; open bar), nonhandling (HMSO; striped bar), postnatal handling (HMSI5; gray bar), and postnatal maternal separation (HMS I80; black bar). Densitometry was performed on 3-4 rostrocaudally matched sections from each animal ( $n=5$ rats/group). Levels were calibrated against ${ }^{14} \mathrm{C}$ standards run on each film. Experimental details and statistical analyses are presented in the text. Data represent mean \pm SEM. * $p<0.05$ or ${ }^{*} * p<0.01$ vs AFR.

levels of CRF mRNA in the PVN $\left(\mathrm{F}_{3,20}=11.35, p<0.01\right)$, CeA $\left(\mathrm{F}_{3,15}=6.79, p<0.05\right)$, BNST $\left(\mathrm{F}_{3,15}=5.82, p<0.05\right)$, and locus coeruleus/parabrachial nucleus (LC/PBN; $\mathrm{F}_{3,15}=$ $4.45, p<0.05)$. In each brain region, the HMS180 rats exhibited significantly greater levels of CRF mRNA than did the AFR animals. There were no significant differences in CRF mRNA density between AFR and HMS15 rats in any region examined. Adult CRF mRNA levels in the HMS180 rats were 2.1 -fold (PVN, $p<0.001$ ), 1.8 -fold (CeA, $p<0.001$ ), 2.2 -fold (BNST, $p<0.001$ ), and 1.5-fold (LC/PBN, $p<0.001$ ) higher than in the AFR groups. Interestingly, CRF mRNA in the PVN of HMSO rats was significantly greater than that of either AFR or HMS15 animals $(p<0.05)$, but was significantly less than that of the HMS180 group.

\section{CRFir Content}

CRF immunoreactivity was measured in tissue micropunch samples from the PVN, CeA, BNST, and LC/PBN. As shown in Figure 4, significant rearing-associated differences in the levels of CRFir were evident in the PVN $\left(\mathrm{F}_{3,28}=\right.$ $38.25, p<0.0001)$, CeA $\left(\mathrm{F}_{3,28}=15.05, p<0.0001\right)$, BNST $\left(\mathrm{F}_{3,28}=18.87, \quad p<0.0001\right), \quad$ and $\mathrm{LC} / \mathrm{PBN} \quad\left(\mathrm{F}_{3,28}=42.22\right.$, $p<0.0001$ ). As was found for CRF mRNA, CRFir was significantly elevated relative to AFR and HMS15 groups in each brain region examined. There were no significant differences in CRFir levels between AFR and HMS15 rats in any region examined. Adult CRFir levels in the HMS180 rats were 1.80 -fold (PVN, $p<0.001$ ), 1.80 -fold (CeA, $p<0.001$ ), 1.92 -fold (BNST, $p<0.001$ ), and 1.91-fold (LC/PBN, $p<0.001)$ higher than in the AFR groups. The HMS0 group was significantly greater than AFR group in the PVN $(p<0.05)$ and BNST $(p<0.05)$. In contrast, the HMS0 rearing group was significantly less than the HMS180 group in the PVN $(p<0.001), \mathrm{CeA}(p<0.01)$, BNST $(p<0.05)$, and LC $(p<0.001)$.

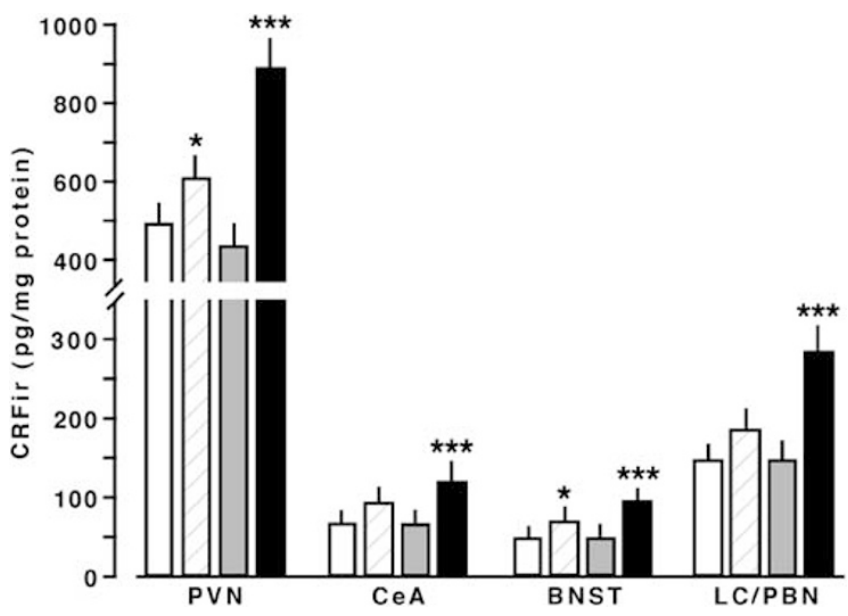

Figure 4 CRFir content in the central nervous system of adult animals reared under conditions of common animal facility rearing (AFR; open bar), nonhandling (HMSO; striped bar), postnatal handling (HMSI5; gray bar), and postnatal maternal separation (HMSI80; black bar). Data represent mean \pm SEM. $* p<0.05$ or $* * * 0.01$ vs AFR ( $n=8$ rats per group). Abbreviations are defined in Figure 3 legend. Experimental details and statistical analyses are presented in the text.

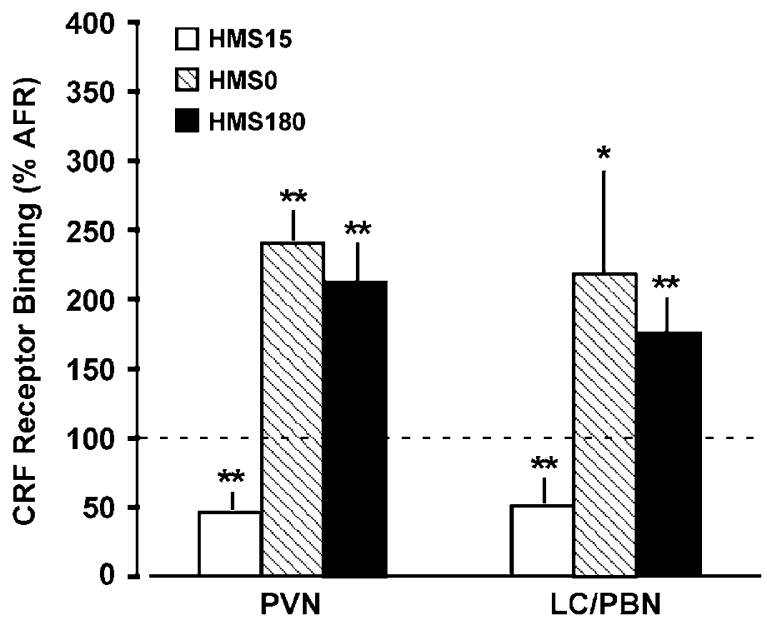

Figure 5 Total CRF receptor binding in the PVN and LC/PBN of handled (HMSI5; open bars), nonhandled (HMSO; striped bars), and maternal separation (HMSI80; black bars) animals expressed as a percentage of values from animal facility reared (AFR) rats. Brain regions were obtained from animals at postnatal day 100. ${ }^{*}<<0.01$ vs AFR.

\section{CRF Receptors}

Total CRF receptor binding was assessed across all rearing groups and the results expressed as the percent binding relative to AFR rats in Figure 5. Total CRF receptor binding was significantly higher in both HMSO $(p<0.05)$ and HMS180 $(p<0.01)$ rats in the PVN and LC. In contrast, CRF receptor binding was significantly reduced $(p<0.01)$ in these regions in the HMS15 rats relative to the AFR animals.

CRF $\alpha$ binding was assessed in the ventromedial hypothalamus (VMH; AFR $329 \pm 37 \mathrm{nCi} / \mathrm{g}$ ), lateral septum (LS; AFR $774 \pm 69 \mathrm{nCi} / \mathrm{g}$ ), and PVN (AFR $248 \pm 36 \mathrm{nCi} / \mathrm{g}$ ). No rearing-associated differences were apparent in CRF2 $\alpha$ binding in any of these regions (data not shown). Similarly, 
no rearing-associated changes in $\mathrm{CRF} 2 \alpha$ mRNA were evident in the VMH (AFR $19 \pm 2.1 \mathrm{nCi} / \mathrm{g}$ ), LS (AFR $13 \pm 1.6 \mathrm{nCi} / \mathrm{g}$ ), or PVN (AFR $10 \pm 1.2 \mathrm{nCi} / \mathrm{g}$ ).

Evaluation of CRF1 binding revealed a significant rearingassociated effect in the PVN $\left(F_{3,16}=24.31, p<0.0001\right)$, the frontal cortex $\left(\mathrm{F}_{3,16}=3.71, p=0.03\right)$, and the LC/PBN region $\left(\mathrm{F}_{3,16}=24.77, p<0.0001\right)$ as shown in Figure $6 \mathrm{a}$. Rearing-associated differences in the basolateral nucleus of the amygdala (BLA) just failed to reach significance $\left(F_{3,16}=3.07, p=0.058\right)$. No significant differences in CRF1 binding were detected between the AFR and HMS15 rearing groups in any region examined. In the PVN, CRF1 expression increased 2.1-fold in HMS180 $(p<0.01)$ and 1.8 -fold in HMS0 rats $(p<0.05) v s$ other rearing groups. CRF1 binding also showed a 2.4 -fold $(p<0.01)$ increase in the LC/PBN region vs HMSAFR and HMS15 rats. In contrast, HMS180 rats displayed a significant decrease in CRF1 binding in the FCTX $(p<0.05)$ as compared to the AFR group. The CRF1 binding in the HMS0 rats was intermediate between HMS180 and AFR rats and was not statistically different from HMS180 levels.

Binding changes were paralleled by changes in CRF1 mRNA in some of these brain regions (Figure 6b). Rearingassociated effects were found in the PVN $\left(\mathrm{F}_{3,16}=8.29\right.$, $p<0.005)$, FCTX $\left(\mathrm{F}_{3,16}=6.05, p<0.01\right)$, and LC/PBN $\left(\mathrm{F}_{3,16}=28.45, p<0.0001\right)$, but not in the BLA $\left(\mathrm{F}_{3,16}=1.30\right.$, $p>0.05)$. CRF1 mRNA was 2.2 -fold $(p<0.01)$ greater in HMS180 than AFR rats and no significant differences were evident between AFR and HMS15 rats. A 2.7-fold $(p<0.001)$ increase was observed in the LC/PBN of HMS180 vs AFR rats with no differences between AFR and HMS15 animals.
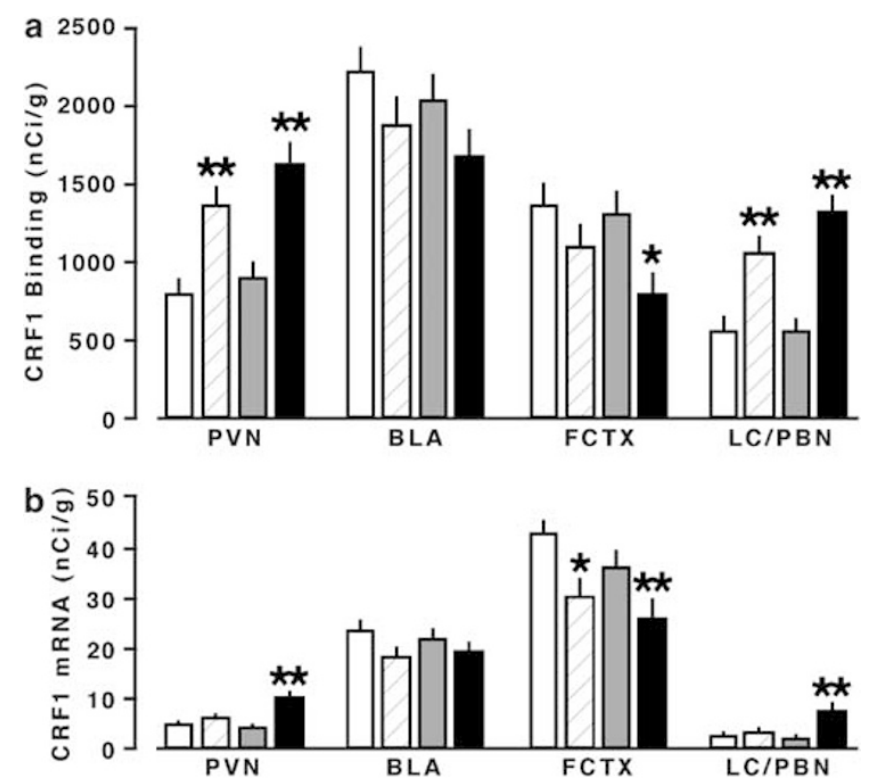

Figure 6 Rearing-associated differences in regional brain CRFI receptor binding (a) and mRNA (b) in adult male rats. The rats were reared under conditions of animal facility rearing (AFR; open bar), nonhandling (HMSO; striped bar), postnatal handling (HMSI5; gray bar), and postnatal maternal separation (HMSI80; black bar) as described in the text. Experimental details and statistical analyses are presented in the text. PVN: paraventricular nucleus; BLA: basolateral nucleus of the amygdala; FCTX: frontal cortex; LC/PBN: locus coeruleus/parabrachial region. Data represent mean \pm SEM. ${ }^{*} p<0.05$ or ${ }^{*} * p<0.01$ vs AFR ( $n=5$ rats per group).
In contrast, there was a $40 \%$ decrease $(p<0.01)$ in CRF1 mRNA in the HMS180 rats $v s$ the AFR animals.

\section{DISCUSSION}

Alterations in maternal behavior within the normal range (Champagne et al, 2003) as well as repeated exposure to moderate periods of maternal separation (Meaney et al, 1996; Ladd et al, 2000; Lehmann and Feldon, 2000) are associated with pronounced long-term changes in responsivity of the HPA axis in rats. As adults, animals exposed to HMS180 and, to a somewhat lesser extent, HMS0 exhibited increased ACTH and CORT responses to a psychological stressor and increased hypothalamic CRFir (Plotsky and Meaney, 1993). In the current study, we demonstrate rearing-associated elevations in CSF CRFir, increased CRF mRNA levels in the PVN, BNST, CeA, and the LC/PBN, and region-specific alterations in $\mathrm{CRF}$ receptor binding and mRNA. Thus, it appears that central CRF systems represent a major target of neonatal rearing conditions in the rat. In fact, this may represent a general response to a wide range of early life stressors in rodents (Dent et al, 2000; Ladd et al, 2000; Schmidt et al, 2002; Fenoglio et al, 2004), monkeys (Coplan et al, 1996), and humans (Raadsheer et al, 1994, 1995; Austin et al, 2003; Newport et al, 2003; Carpenter et al, 2004).

Adult HMS180 rats exhibit normal circadian trough ACTH and CORT levels, yet demonstrate profound hypersecretion in response to the psychological stressor of airpuff startle (Figure 1a and b). This pattern of hyperresponsiveness has also been reported in several nonhuman primate models of early adversity (Coplan et al, 1996; Smith et al, 2002) and in adult women with a history of prepubertal abuse (Heim et al, 2000, 2002; Heim and Nemeroff, 2001). Changes in nervous system CRF tone appear to be associated with these changes in HPA responsiveness, as illustrated by elevations in CSF CRFir in the adult HMS180 rats (Figure 2), in several primate models of early adversity (Coplan et al, 1996; Maestripieri et al, 2005), primates with fearful temperaments (Kalin et al, 2000), and in abused children as well as in adult women with a history of abuse (Heim and Nemeroff, 2001; Newport et al, 2003; Carpenter et al, 2004). Alternatively, we recently reported blunting of the diurnal cortisol rhythm in rhesus monkeys exposed to early adversity without accompanying changes in CSF CRFir (Sanchez et al, 2005). This difference may be developmentally related or represent a species difference.

Ladd et al (1996) reported that maternal separation increased CRFir in the LC and neighboring PBN. These structures appear to receive CRF projections from the CeA (see Gray, 1989; Van Bockstaele et al, 2001). Indeed, lesions to the CeA produce an $80-85 \%$ decrease in CRFir in the region of the LC (Koegler-Muly et al, 1993). The elevation of CSF CRFir in HMS180 rats is consistent with reports from clinical studies of depression and abuse (Banki et al, 1987; De Bellis et al, 1993; Geracioti et al, 1992; Nemeroff et al, 1991; Newport et al, 2003). Taken together with our previous reports showing increased hypothalamic and median eminence CRFir in HMS180 animals (Plotsky and Meaney, 1993), these findings suggest that CRF gene 
expression and peptide synthesis within the PVN and CeALC systems may represent a common target in animals exposed to what may be considered abnormal neonatal rearing conditions regardless of which end of the rearing spectrum they fall into-monotonous housing and care (ie HMS0) vs extended periods of neonatal maternal separation (ie HMS180). The observation that both the HMS180 and HMS0 rearing conditions result in a similar directionality of changes in these CRF systems is a conundrum that is difficult to reconcile (see below).

In contrast, animals exposed to either HMS15 or AFR rearing conditions exhibit comparable levels of CRF mRNA in the PVN and CeA as well as similar concentrations of CRFir in the median eminence (also see Plotsky and Meaney, 1993; Viau et al, 1993) and LC. This is not unexpected as care protocols in most breeding colonies expose animals to repeated cage cleaning during the first 2 weeks of life that involve transferring the mother and the pups from the maternity cage to a clean, novel cage, and may therefore be considered as variant of the handling procedure (Greenberg and Bursdal, 1982). As we show here with respect to CRF and as we and others have previously reported, both routine animal husbandry protocols (eg AFR) and the HMS15 protocol produce similar neurobehavioral outcomes (Caldji et al, 2000; Pryce et al, 2001; Pryce and Feldon, 2003). However, Fenoglio et al (2004) recently reported that handling during PND2-9 was associated with a transient increase of CRF mRNA in the CeA by PND6, a transient increase of peptide levels in BNST, and a longlasting decrease of CRF levels in PVN beginning by PND9. Importantly, these changes in CRF preceded changes in hippocampal GR expression by many weeks. It is noteworthy that a majority of the rodent neuroscience and behavioral literature is derived from studies on what are essentially animal facility reared rats; therefore, we propose that the AFR group is an appropriate comparison or colony control group for these types of experiments.

The HMSO rats represent a problematical group with respect to their tendency to approximate the HMS180 group on many outcome variables such as enhanced behavioral fearfulness (Francis et al, 1999; Caldji et al, 2000), reduced hippocampal GR mRNA (Meaney et al, 1996; Avishai-Eliner et al, 2001), and enhanced PVN CRF mRNA (see Figure 3). The question of why the neonatal experiences of being either undisturbed (eg HMS0) or maternally separated (HMS180) exert a similar effect on the phenotype of the offspring awaits a definitive answer. This observation appears to contradict the 'maternal mediation hypothesis' (Denenberg et al, 1962; Denenberg, 1999), according to which differences in maternal care upon reunion of the dam with her pups may account for a significant portion of the neurobehavioral differences in the adult offspring (Suchecki et al, 1993; Meaney, 2001).

The environmental impoverishment inherent in standard laboratory rodent housing may render the HMS0 rats more fearful and reactive than HMS15 animals (Bors and Forrin, 1996; Rosenzweig and Bennett, 1996; Larsson et al, 2002). According to Macri et al (2004), the difference in neurobehavioral phenotype between HMS0 and handled offspring reflects adaptive plasticity in the HPA axis and behavioral function with respect to energy utilization and overall health. In this view, HMS0 rats live in a relatively stress-free environment and, therefore, retain a highly reactive stress response while HMS15 rats that have been exposed to repetitive stressors adapt by downregulating HPA axis responsiveness. The enhanced responsiveness of the HMS180 rats, considered to be maladaptive, reflects disruption of normal pup homeostasis and in the intervals between nursing bouts as a result of the repeated, prolonged neonatal separations.

Disruption of the perceived safety of the nest area by the maternal separation protocol, as well as the actual physical separation of the dam from her pups, may elicit changes in behavior of the dam (Kalinichev et al, 2000; Fleming et al, 2002). In fact, we (Ladd et al, 2000; Huot et al, 2004) have proposed that in response to maternal separation, the quantity and/or quality of dam-pup interaction differs from that observed in AFR, HMS15, and HMS0 groups. Although each individual measure may exhibit only a small change, appropriate coordination of the sequence of maternal behavior may be altered. It should be noted that in a majority of the studies in which maternal behavior was measured, it was either the frequency and/or duration of the occurrence of particular maternal behaviors that was recorded (Champagne et al, 2003; Pryce et al, 2001; Stern, 1997). However, our own ongoing observations using Markov chain analysis indicate that the normally coordinated pattern of maternal behaviors may be disrupted in the HMS180 condition and that this disorganization of the sequencing of maternal behaviors may be equally or even more important than the frequency or duration of occurrence of isolated behaviors.

Differences in amygdaloid CRF expression are of interest considering the effects of early life events on behavioral responses to stress. The CeA has long been implicated in the expression of autonomic and behavioral responses to stress (reviewed in Davis, 1992; LeDoux, 1992, 1994; Gray, 1993). Lesions of the CeA have been found to block many of the behavioral effects associated with stress and the literature on the role of the amygdala in conditioned emotional responses is especially rich. Lesions of the CeA block the excitatory effects of both conditioned and unconditioned fear on startle responses (Hitchcock and Davis, 1986, 1989) and the development of conditioned emotional responses (van der Kar et al, 1991; LeDoux, 1994). Interestingly, both the central and the lateral nucleus of the amygdala have been found to be important substrates for the anxiolytic effects of benzodiazepines on stress-related behaviors.

These amygdaloid effects are at least partially mediated by CRF. Pich et al (1995), using in vivo microdialysis, reported an increase in extracellular CRFir levels in the amygdala in response to stress and ethanol withdrawal. Microinjections of the CRF antagonist $\alpha$-helical $\mathrm{CRF}_{9-41}$ into the CeA block the anxiogenic effects of ethanol withdrawal (Rassnick et al, 1993), fear-induced freezing (Swiergiel et al, 1993), and increased emotionality following social defeat (Heinrichs et al, 1992b). In contrast, CRF microinjections into the amygdala decrease exploratory behavior in an open-field test (Liang and Lee, 1988; Elkabir et al, 1990) and increase defensive aggression (Elkabir et al, 1990). Finally, lesions of the CeA block the excitatory effects of CRF on the acoustic startle reflex (Liang et al, 1992a). However, it must be noted that in attempting to extrapolate these observations to human psychopathology, one must take into account 
species differences in the distribution of both CRF and its receptor subtypes (Sanchez et al, 1999, 2001). Thus, CRF acts at the level of the amygdala to mediate the expression of behavioral responses to fear and, predictably, the observed changes in this system in response to rearing condition altered anxiety-like behavior.

CRF also serves as a neurotransmitter/neuromodulator in the projection from the amygdala to the LC and neighboring PBN (Moga and Gray, 1989). The LC has long been considered as a major site for mediation of anxiety-like states in primates and rodents (see Schulkin et al, 1994 for review). This structure sends noradrenergic projections extending throughout multiple cortical and subcortical regions, including the prefrontal cortex, the hippocampus, the amygdala, and the hypothalamus (Foote et al, 1983). Stress increases CRF concentrations in the LC (Chappell et al, 1986) and LC injection of CRF is associated with increased catecholamine release in the hypothalamus and prefrontal cortex of freely moving rats (Lavicky and Dunn, 1993). Both stress and CRF infusion have been shown to increase the firing rate of LC neurons and to stimulate the autonomic nervous system (Brown, 1989). The effects on LC can be blocked by local injections of the CRF receptor antagonist $\alpha$-helical $\mathrm{CRF}_{9-41}$ (Valentino and Foote, 1988; Valentino et al, 1998). Microinjections of a CRF receptor antagonist into the LC also attenuate novelty-induced suppression of exploratory behavior in the defensive withdrawal paradigm (Butler et al, 1990), as well as stressinduced behavioral freezing (Swiergiel et al, 1993). In addition to changes in CRF expression, we found increased CRF receptor binding capacity in the pericoerulear region of both HMS180 and HMS0 rats (Figure 5). Both specific CRF1 receptor binding and mRNA were increased in HMS180 rats vs AFR and HMS15 rats (Figure 6). The CRF1 receptor subtype is associated with enhanced anxiogeneic effects (Streckler and Holsboer, 1999). Taken together, these data suggest that changes in CRF tone to the LC and related areas may change the sensitivity (ie alter the set-point) of these pathways to stimuli that normally activate them.

These observations imply that there would be increased CRF-induced activation of the LC during stress in the HMS0 and HMS180 animals. At least two findings are consistent with this idea. In comparison to HMS15 rats, acute restraint stress in both HMS0 and HMS180 rats is associated with a greater increase in Fos-ir in the LC (Pearson et al, 1997) and larger increases in extracellular NE levels in the PVN (Liu et al, 2000). In a recent post-mortem study of depressed suicide victims, Austin et al (2003) observed increased CRFir in the LC as well as median and dorsal raphe neurons. Thus, we propose that the neonatal environment can regulate the expression of behavioral responses to stress, at least in part, by altering the set-point of the CeA/BNSTLC CRF-NE system during a developmentally sensitive window occurring during the 10-14 days immediately after birth.

The behavioral differences in stress responsiveness noted between AFR and HMS15 vs HMS0 and HMS180 animals parallel those found in HPA axis responsiveness. Maternal separation increases plasma ACTH and CORT responses to acute psychological stressors (ie stressors involving conditions that signal threat) as compared to HMS15 or AFR rats (see Meaney et al, 1996 for review). These differences in
HPA axis responsivity to stress are, in part, associated with differential expression of $\mathrm{CRF}$, as well as arginine vasopressin (AVP) in parvocellular neurons of the PVN (Plotsky and Meaney, 1993; Viau et al, 1993; Bhatnagar et al, 1995). These neurons project to the external zone of the median eminence and provide the neurohumoral signal for the release of ACTH from pituitary corticotrophs (see Plotsky, 1991 for review). Thus, our current findings of increased PVN CRF mRNA expression as well as increased CRF peptide content in the median eminence terminals of HMS180 and HMS0 rats (Plotsky and Meaney, 1993) provide strong support for the thesis that the neuroendocrine CRF system and, thus, HPA axis responsivity, is sensitive to the early rearing environment. The upregulation of CRF1 receptors in the PVN of HMS180 rats without a change in CRF2 binding or mRNA suggests functional adaptation in this region. Previous reports of CRF- and stress-induced upregulation have appeared (Rivest et al, 1995; Imaki et al, 1996; Mansi et al, 1996). Remarkably similar endocrine findings have been reported in depressed women with a history of childhood sexual or physical abuse (Heim and Nemeroff, 2001; Heim et al, 2002).

The effects of neonatal rearing on the PVN median eminence and the CeA/BNST-LC neurocircuits are likely to ramify throughout the brain to modify additional neurotransmitter circuits, which together may contribute to differences in behavioral and neuroendocrine responsiveness to stressors. In addition to the LC, Ladd et al (1996) found that maternal separation increased $\mathrm{CRF}$ receptor binding in the raphe nuclei. This region also shows increased CRFir in depressed suicide victims (Austin et al, 2003). Due to the anatomical and functional relationships among these structures, these findings suggest that early experience-induced changes in CRF systems may lead to a cascade of adaptations including both the noradrenergic and serotonergic systems, thus rendering the individual more responsive to subsequent stressors.

It is likely that similar changes in these systems also contribute to human psychopathology. Indeed, in humans, abuse or neglect in early life has been repeatedly shown to be a major risk factor for depression and/or anxiety disorders in adulthood (Bifulco et al, 1991; Brown and Anderson, 1993; Mullen et al, 1996; McCauley et al, 1997; Weiss et al, 1999; Bulik et al, 2001; Molnar et al, 2001; Kendler et al, 2002). Hyperactivity of central CRF systems has been implicated in the expression of these affective disorders (Stout and Nemeroff, 1994; Heim and Nemeroff, 2001; Heim et al, 2002, 2004), and both noradrenergic and serotonergic systems appear to be involved in the development of affective disorders.

Overall, these findings provide further validation of neonatal maternal separation in rats as a model of vulnerability to an anxiety- and depression-like syndrome. Altered rearing conditions are strongly associated with persistent alterations in stress-responsive neurocircuits. This process, which may occur via altered methylation of target genes in a region-specific pattern (Weaver et al, 2004a, b), or other mechanisms serve to 'tune' stress-sensitive neurocircuits in an adaptive or maladaptive manner. Specifically, this study strengthens the linkage between early life environment and long-term alterations in central CRF systems. These findings may provide a mechanism whereby life events, 
interacting with genetic predisposition, may increase vulnerability to pathology in later life.

\section{ACKNOWLEDGEMENTS}

This research was supported by the NIMH-funded Silvio O Conte Center for the Neuroscience of Mental Disease (MH58922; CBN, PMP) and by Grants MH50113 (PMP, MJM) and MH42088 (CBN). PMP has received speaking fees from Janssen Pharmaceutica, Johnson \& Johnson Pharmaceutical Research \& Development, LLC, and Roche Palo Alto, LLC, as well as research support from Johnson \& Johnson Pharmaceutical Research \& Development, LLC, Pharmacia Upjohn, Synaptic/Lunbeck, and NV Organon. PMP is the recipient of a GlaxoSmithKline endowed chair in Psychiatry and Behavioral Science. CBN has received consulting fees, speaking fees, research support, or other financial support from Abbott Laboratories, Acadia Pharmaceuticals, AstraZeneca, Bristol-Myers Squibb, Corcept, Cypress Biosciences, Cyberonics, Eli Lilly, Forest Laboratories, GlaxoSmithKline, Janssen Pharmaceutica, Merck, Neurocrine Biosciences, Novartis, Organon, Otsuka, SanofiSynthelabo, Somerset, Pfizer Pharmaceuticals, and WyethAyerst. MJM was also supported by a grant from the Canadian Institutes of Health Research and a Senior Scientist award. CC was supported by a graduate fellowship from the Canadian Institutes of Health Research.

\section{REFERENCES}

Arase K, York DA, Shimizu H, Shargill N, Bray GA (1988). Effects of corticotropin-releasing factor on food intake and brown adipose tissue thermogenesis in rats. Am J Physiol 255: E255E259.

Arborelius L, Owens MJ, Plotsky PM, Nemeroff CB (1999). The role of corticotropin-releasing factor (CRF) in depression and anxiety disorders. J Endocrinol 160: 1-12.

Austin MC, Janosky JE, Murphy HA (2003). Increased corticotropin-releasing hormone immunoreactivity in monoaminecontaining pontine nuclei of depressed suicide men. Mol Psychiatry 8: 324-332.

Avishai-Eliner S, Eghbal-Ahmadi M, Tabachnik E, Brunson KL, Baram TZ (2001). Down-regulation of corticotropin-releasing hormone messenger ribonucleic acid (mRNA) precedes early-life experience-induced changes in hippocampal glucocorticoid receptor mRNA. Endocrinology 142: 89-97.

Banki CM, Bissette G, Arato M, O'Connor L, Nemeroff CB (1987). Cerebrospinal fluid corticotropin-releasing factor-like immunoreactivity in depression and schizophrenia. Am J Psychiatry 144: 873-877.

Berridge CW, Dunn AJ (1987). A corticotropin-releasing factor antagonist reverses the stress induced changes of exploratory behavior in mice. Horm Behav 21: 393-401.

Bhatnagar S, Shanks N, Meaney MJ (1995). Hypothalamicpituitary-adrenal function in handled and nonhandled rats in response to chronic stress. J Neuroendocrinol 7: 107-119.

Bifulco A, Brown GW, Adler Z (1991). Early sexual abuse and clinical depression in aduult life. Br J Psychiat 159: 115-122.

Bors DA, Forrin B (1996). The effects of post-weaning environment, biological dam, and nursing dam on feeding neophobia, open field activity, and learning. Can J Exp Psychol 50: 197-204.

Britton DR, Hoffman DK, Lederis K, Rivier JA (1984). Comparison of the behavioral effects of GRF, sauvagine and urotensin I. Brain Res 304: 201-205.
Britton DR, Koob GF, Rivier J, Vale W (1982). Intraventricular corticotropin-releasing factor enhances behavioral effects of novelty. Life Sci 31: 363-367.

Brown GR, Anderson B (1993). Psychiatric morbidity in adult inpatients with childhood histories of sexual and physical abuse. Am J Psychiat 148: 55-61.

Brown MR (1989). Neuropeptide regulation of the autonomic nervous system. In: Taché Y, Morley JE, Brown MR (eds). Neuropeptides and Stress. Springer-Verlag: New York. pp 107120.

Bulik CM, Prescott CA, Kendler KS (2001). Features of childhood sexual abuse and the development of psychiatric and substance use disorders. Br J Psychiatry 179: 444-449.

Butler PD, Weiss JM, Stout JC, Nemeroff CB (1990). Corticotropinreleasing factor produces fear-enhancing and behavioural activating effects following infusion into the locus coeruleus. J Neurosci 10: 176-183.

Cador M, Ahmed SH, Koob GF, Le Moal M, Stinus L (1992). Corticotropin-releasing factor induces a place aversion independent of its neuroendocrine role. Brain Res 41: 61-69.

Caldji C, Francis D, Sharma S, Plotsky PM, Meaney MJ (2000). The effects of early rearing environment on the development of $\mathrm{GABA}_{\mathrm{A}}$ and central benzodiazepine receptor levels and noveltyinduced fearfulness in the rat. Neuropsychopharmacology 22: 219-229.

Carpenter LL, Tyrka AR, McDougle CJ, Malison RT, Owens MJ, Nemeroff CB et al (2004). Cerebrospinal fluid corticotropinreleasing factor and perceived early-life stress in depressed patients and healthy controls. Neuropsychopharmacology 29: 777-784.

Champagne FA, Francis DD, Mar A, Meaney MJ (2003). Variations in maternal care in the rat as a mediating influence for effects of environment on development. Physiol Behav 79: 359-371.

Chappell PB, Smith MA, Kitts CD, Bisette G, Ritchie J, Anderson C et al (1986). Alterations in corticotropin-releasing factor-like immunoreactivity in discrete rat brain regions after acute and chronic stress. J Neurosci 6: 2908-2914.

Chrousos GP, Gold PW (1992). The concepts of stress and stress system disorders. JAMA 267: 1244-1252.

Coplan JD, Andrews MW, Rosenblum LA, Owens MJ, Friedman S, Gorman JM et al (1996). Persistent elevations of cerebrospinal fluid concentrations of corticotropin-releasing factor in adult nonhuman primates exposed to early-life stressors: implications for the pathophysiology of mood and anxiety disorders. Proc Natl Acad Sci USA 93: 1619-1623.

Davis M (1992). The role of the amygdala in fear and anxiety. Annu Rev Neurosci 15: 353-375.

De Bellis MD, Gold PW, Geracioti TD, Listwak SJ, Kling MA (1993). Fluoxetine significantly reduces CSF CRH and AVP concentrations in patients with major depression. Am J Psychiatry 150: 656-657.

De Souza EB (1987). Corticotropin releasing factor receptors in the rat central nervous system: characterization and regional distribution. J Neurosci 7: 88-100.

De Souza EB, Insel TR, Perrin MH, Rivier J, Vale WW, Kuhar MJ (1985). Corticotropin-releasing factor receptors are widely distributed with the rat central nervous system, an autoradiographic study. J Neurosci 5: 3189-3202.

Denenberg VH (1964). Critical periods, stimulus input, and emotional reactivity: a theory of infantile stimulation. Psychol Rev 71: 335-351.

Denenberg VH (1999). Commentary: is maternal stimulation the mediator of the handling effect in infancy. Dev Psychobiol 34: 1-3.

Denenberg VH, Ottinger DR, Stephens MW (1962). Effects of maternal factors upon growth and behavior of the rat. Child Dev 33: 65-71. 
Dent GW, Okimoto DK, Smith MA, Levine S (2000). Stress-induced alterations in corticotropin-releasing hormone and vasopressin gene expression in the paraventricular nucleus during ontogeny. Neuroendocrinology 71: 333-342.

Dunn AJ, Berridge GW (1990). Physiological and behavioral responses to corticotropin releasing factor administration: is CRF a mediator of anxiety or stress responses? Brain Res Rev 15: 71-100.

Elkabir DR, Wyatt ME, Vellucci SV, Herbert J (1990). The effects of separate or combined infusions of corticotropin-releasing factor and vasopressin either intraventricularly or into the amygdala on aggressive and investigative behavior in the rat. Regul Pept 28: 199-214.

Engelmann M, Thrivikraman KV, Su Y, Nemeroff CB, Montkowski A, Landgraf $\mathrm{R}$ et al (1996). Endocrine and behavioral effects of airpuff-startle in rats. Psychoneuroendocrinology 21: 391-400.

Fenoglio KA, Brunson KL, Avishai-Eliner S, Chen Y, Baram TZ (2004). Region-specific handling-induced changes in corticotropin-releasing factor and glucocorticoid receptor expression. Endocrinology 145: 2702-2706.

Fleming AS, Kraemer GW, Gonzalez A, Lovic V, Rees S, Melo A (2002). Mothering begets mothering: the transmission of behavior and its neurobiology across generations. Pharmacol Biochem Behav 73: 61-75.

Foote SL, Bloom FE, Aston-Jones G (1983). Nucleus locus ceruleus: new evidence of anatomical and physiological specificity. Physiol Rev 63: 844-914.

Francis DD, Caldji C, Champagne F, Plotsky PM, Meaney MJ (1999). The role of corticotropin-releasing factor-norepinephrine systems in mediating the effects of early experience on the development of behavioral and endocrine responses to stress. Biol Psychiatry 46: 1153-1166.

Geracioti TD, Orth DN, Ekhator NN, Blumenkopf B, Loosen PT (1992). Serial cerebrospinal fluid corticotropin-releasing hormone concentrations in healthy and depressed humans. J Clin Endocrinol Metab 74: 1325-1330.

Gray TS (1989). The organization and possible function of amygdaloid corticotropin-releasing factor pathways. In: De Souza EB, Nemeroff CB (eds). Corticotropin-Releasing Factor: Basic and Clinical Studies of a Neuropeptide. CRC Press: Boca Raton. pp 53-68.

Gray TS (1993). Amygdaloid CRF pathways. Role in autonomic, neuroendocrine, and behavioral responses to stress. Ann NY Acad Sci 697: 53-60.

Greenberg G, Bursdal C (1982). Animal colony practices in North American academic institutions: a survey. J Gen Psychol 106: 165-173.

Heim C, Nemeroff CB (2001). The role of childhood trauma in the neurobiology of mood and anxiety disorders: preclinical and clinical studies. Biol Psychiatry 49: 1023-1039.

Heim C, Newport DJ, Heit S, Graham YP, Wilcox M, Bonsall R et al (2000). Pituitary-adrenal and autonomic responses to stress in women after sexual and physical abuse in childhood. JAMA 284: 592-597.

Heim C, Newport DJ, Wagner D, Wilcox MM, Miller AH, Nemeroff CB (2002). The role of early adverse experience and adulthood stress in the prediction of neuroendocrine stress reactivity in women: a multiple regression analysis. Depress Anxiety 15: 117-125.

Heim C, Plotsky PM, Nemeroff CB (2004). Importance of studying the contributions of early adverse experience to neurobiological findings in depression. Neuropsychopharmacology 29: 641-648.

Heinrichs SC, Cole BJ, Pich EM, Menzaghi F, Koob GF, Hauger RL (1992a). Endogenous corticotropin-releasing factor modulates feeding induced by neuropeptide $\mathrm{Y}$ or a tail pinch stressor. Peptides 13: 879-884.

Heinrichs SC, Menzaghi F, Pich EM, Hauger RL, Koob GF (1993). Corticotropin-releasing factor in the paraventricular nucleus modulates feeding induced by neuropeptide Y. Brain Res 611: $18-24$.

Heinrichs SC, Pich EM, Miczek K, Britton KT, Koob GF (1992b). Corticotropin-releasing factor antagonist reduces emotionality in socially defeated rats via direct neurotropic action. Brain Res 581: 190-197.

Hitchcock JM, Davis M (1986). Lesions of the amygdala, but not of the cerebellum or red nucleus, block conditioned fear as measured with the potentiated startle paradigm. Behav Neurosci 100: $11-22$.

Hitchcock JM, Sananes CB, Davis M (1989). Sensitization of the startle reflex by footshock: blockade by lesions of the central nucleus of the amygdala or its efferent pathway to the brainstem. Behav Neurosci 103: 509-518.

Hofer MA (1994). Early relationships as regulators of infant physiology and behavior. Acta Paediatr Suppl 397: 9-18.

Huot RL, Gonzalez ME, Ladd CO, Thrivikraman KV, Plotsky PM (2004). Foster litters prevent hypothalamic-pituitary-adrenal axis sensitization mediated by neonatal maternal separation. Psychoneuroendocrinology 29: 279-289.

Huot RL, Thrivikraman KV, Meaney MJ, Plotsky PM (2001). Development of adult ethanol preference and anxiety as a consequence of neonatal maternal separation in Long Evans rats and reversal with antidepressant treatment. Psychopharmacology 158: 366-373.

Imaki T, Naruse M, Harada S, Chikada N, Imaki J, Onodera H et al (1996). Corticotropin-releasing factor up-regulates its own receptor mRNA in the paraventricular nucleus of the hypothalamus. Mol Brain Res 38: 166-170.

Imaki T, Shibasaki T, Masuda A, Demura H, Shizume K, Ling N (1987). Effects of adrenergic blockers on corticotropin-releasing factor-induced behavioral changes in rats. Regul Pept 19: $243-$ 252.

Jans J, Woodside BC (1990). Nest temperature: effects on maternal behavior, pup development, and interactions with handling. Dev Psychobiol 23: 519-534.

Kalin NH, Shelton SE, Davidson RJ (2000). Cerebrospinal fluid corticotropin-releasing hormone levels are elevated in monkeys with patterns of brain activity associated with fearful temperament. Biol Psychiatry 47: 579-585.

Kalinichev M, Easterling KW, Holtzman SG (2000). Periodic postpartum separation from the offspring results in longlasting changes in anxiety-related behaviors and sensitivity to morphine in Long-Evans mother rats. Psychopharmacology 152: 431-439.

Kendler KS, Gardner CO, Prescott CA (2002). Toward a comprehensive developmental model for major depression in women. Am J Psychiatry 159: 1133-1145.

Koegler-Muly SM, Owens MJ, Ervin GN, Kilts CD, Nemeroff CB (1993). Potential corticotropin-releasing factor pathways in the rat brain as determined by bilateral electrolytic lesions of the central amygdaloid nucleus and paraventricular nucleus of the hypothalamus. J Neuroendocrinol 5: 95-98.

Koob GF (1999). Corticotropin-releasing factor, norepinephrine, and stress. Biol Psychiatry 46: 1167-1180.

Koob GF, Heinrichs SC, Menzaghi F, Pich EM, Britton KT (1994). Corticotropin releasing factor, stress and behavior. Semin Neurosci 6: 221-229.

Krahn DD, Gosnell BA, Grace M, Levine AS (1986). CRF antagonist partially reverses CRF- and stress-induced effects on feeding. Brain Res Bull 17: 285-289.

Ladd CO, Huot RL, Thrivikraman KV, Nemeroff CB, Meaney MJ, Plotsky PM (2000). Long-term behavioral and neuroendocrine adaptations to adverse early experience. Prog Brain Res 122: 81-103.

Ladd CO, Owens MJ, Nemeroff CB (1996). Persistent changes in corticotropin-releasing factor neuronal systems induced by maternal deprivation. Endocrinology 137: 1212-1318. 
Larsson F, Winblad B, Mohammed AH (2002). Psychological stress and environmental adaptation in enriched $v s$. impoverished housed rats. Pharmacol Biochem Behav 73: 193-207.

Lavicky J, Dunn AJ (1993). Corticotropin-releasing factor stimulates catecholamine release in hypothalamus and prefrontal cortex in freely moving rats as assessed by microdialysis. $J$ Neurochem 60: 602-612.

LeDoux JE (1992). Emotion and the amygdala. In: Aggleton JP (ed). The Amygdala: Neurobiological Aspects of Emotion, Memory, and Mental Dysfunction. Wiley-Liss: New York. pp 339-351.

LeDoux JE (1994). The amygdala: contributions to fear and stress. Semin Neurosci 6: 231-237.

Lehmann J, Feldon J (2000). Long-term biobehavioral effects of maternal separation in the rat: consistent or confusing? Rev Neurosci 11: 383-408.

Lejeune F, Millan MJ (2003). The CRF1 receptor antagonist, DMP695, abolishes activation of locus coeruleus noradrenergic neurones by CRF in anesthetized rats. Eur J Pharmacol 464: 127-133.

Levine S (1975). Psychosocial factors in growth and development. In: Levi L (ed). Society, Stress and Disease. Oxford University Press: London. pp 43-50.

Liang KC, Lee EHY (1988). Intra-amygdala injections of corticotropin-releasing factor facilitate inhibitory avoidance learning and reduce exploratory behavior in rats. Psychopharmacology 96: 232-236.

Liang KC, Melia KR, Miserendino MJ, Fails WA, Campeau S, Davis M (1992b). Corticotropin releasing factor: long-lasting facilitation of the acoustic startle reflex. J Neurosci 12: 2303-2312.

Liang KC, Melia KR, Campeau S, Falls WA, Miserendino MJ, David $M$ (1992a). Lesions of the central nucleus of the amvgdala, but not the paranventricular nucleus of the hypothalamus, block the excitatory effects of corticotropin releasing factor on the acoustic startle reflex. J Neurosci 12: 2313-2320.

Liu D, Caldji C, Sharma S, Plotsky PM, Meaney MJ (2000). Influence of neonatal rearing condition on stress-induced adrenocorticotropin responses and norepinephrine release in the hypothalamic paraventricular nucleus. J Neuroendocrinol 12: $5-12$.

Liu D, Tannenbaum B, Caldji C, Francis D, Freedman A, Sharma S et al (1997). Maternal care, hippocampal glucocorticoid receptor gene expression and hypothalamic-pituitary-adrenal responses to stress. Science 277: 1659-1662.

Macri S, Mason GJ, Wurbel H (2004). Dissociation in the effects of neonatal maternal separations on maternal care and the offspring's HPA and fear responses in rats. Eur J Neurosci 20: 1017-1024.

Maestripieri D, Lindell SG, Ayala A, Gold P, Higley JD (2005). Neurobiological characteristics of rhesus macaque abusive mothers and their relation to social and maternal behavior. Neurosci Neurobehav Rev 29: 51-57.

Mansi JA, Rivest S, Drolet G (1996). Regulation of corticotropinreleasing factor type 1 (CRF1) receptor messenger ribonucleic acid in the paraventricular nucleus of rat hypothalamus by exogenous CRF. Endocrinology 137: 4619-4629.

McCauley J, Kern D, Kolodner K (1997). Clinical characteristics of women with a history of childhood abuse. JAMA 277: 1362-1368.

Meaney MJ (2001). Maternal care, gene expression, and the transmission of individual differences in stress reactivity across generations. Annu Rev Neurosci 24: 1161-1192.

Meaney MJ, Diorio J, Widdowson J, LaPlante P, Caldji C, Seckl JR et al (1996). Early environmental regulation of forebrain glucocorticoid receptor gene expression: implications for adrenocortical responses to stress. Dev Neurosci 18: 49-72.

Menzaghi F, Heinrichs SC, Pich EM, Tilders FJH, Koob GF (1993). Functional impairment of hypothalamic corticotropin-releasing factor neurons with immunotargeted toxins enhances food intake induced by neuropeptide Y. Brain Res 618: 76-82.
Moga MM, Gray TS (1989). Evidence for corticotropin-releasing factor, neurotensin, and somatostatin in the neural pathway from the central nucleus of the amygdala to the parabrachial nucleus. J Comp Neurol 241: 275-284.

Molnar BE, Buka SL, Kessler RC (2001). Child sexual abuse and subsequent psychopathology: results from the National Comorbidity Survey. Am J Public Health 91: 753-760.

Moore CL, Morelli GA (1979). Mother rats interact differently with male and female offspring. J Comp Physiol Psychol 93: 677-684.

Mullen PE, Martin JL, Anderson JC, Romans SE, Herbison GP (1996). The long-term impact of the physical, emotional, and sexual abuse of children: a community study. Child Abuse Negl 20: 7-21.

Nemeroff CB, Bissette G, Akil H, Fink M (1991). Neuropeptide concentrations in the cerebrospinal fluid of depressed patients treated with electroconvulsive therapy: corticotropin-releasing factor, $\beta$-endorphin, and somatostatin. $\mathrm{Br} J$ Psychiatry 158: 59-63.

Newport DJ, Heim C, Owens MJ, Ritchie JC, Ramsey CH, Bonsall R et al (2003). Cerebrospinal fluid corticotropin-releasing factor (CRF) and vasopressin concentrations predict pituitary response in the CRF stimulation test: a multiple regression analysis. Neuropsychopharmacology 28: 569-576.

Owens MJ, Nemeroff CB (1991). The physiology and pharmacology of corticotropin-releasing factor. Pharmacol Rev 43: 425-473.

Page ME, Valentino RJ (1994). Locus coeruleus activation by physiological challenges. Brain Res Bull 35: 557-560.

Palkovits M, Brownstein MJ (1988). Maps and Guide to Microdissection of the Rat Brain. Elsevier: New York.

Paxinos G, Watson C (1986). The Rat Brain in Stereotaxic Coordinates. Academic Press: San Diego.

Pearson D, Sharma S, Plotsky PM, Pfaus JG, Meaney MJ (1997). The effect of postnatal environment on stress-induced changes in hippocampal FOS-like immunoreactivity in adult rats. Soc Neursci Abstr 23: 1849.

Pich EM, Lorang M, Yeganeh M, Rodriguez de Fonseca F, Raber J, Koob GF et al (1995). Increase of extracellular corticotropinreleasing factor-like immunoreactivity levels in the amygdala of awake rats during restraint stress and ethanol withdrawal as measured by microdialysis. J Neurosci 15: 5439-5447.

Plotsky PM (1991). Pathways to the secretion of adrenocorticotropin: a view from the portal. J Neuroendocrinol 3: 1-9.

Plotsky PM, Bruhn TO, Vale WW (1985). Evidence for multifactor regulation of the adrenocortical secretory response to hemodynamic stimuli. Endocrinology 116: 633-639.

Plotsky PM, Cunningham ET, Widmaier EP (1989). Catecholaminergic modulation of corticotropin-releasing factor and adrenocorticotropin secretion. Endocr Rev 10: 437-458.

Plotsky PM, Meaney MJ (1993). Early, postnatal experience alters hypothalamic corticotropin-releasing factor (CRF) mRNA, median eminence CRF content and stress-induced release in adult rats. Mol Brain Res 18: 195-200.

Primus RJ, Yevich E, Baltazar C, Gallager DW (1997). Autoradiographic localization of CRF1 and CRF2 binding sites in adult rat brain. Neuropsychopharmacology 17: 308-316.

Pryce CR, Bettschen D, Feldon J (2001). Comparison of the effects of early handling and early deprivation on maternal care in the rat. Dev Psychobiol 38: 239-251.

Pryce CR, Feldon J (2003). Long-term neurobehavioural impact of the postnatal environment in rats: manipulations, effects and mediating mechanisms. Neurosci Biobehav Rev 27: 57-71.

Raadsheer FC, Hoogendijk WJ, Stam FC, Tilders FJ, Swaab DF (1994). Increased numbers of corticotropin-releasing hormone expressing neurons in the hypothalamic paraventricular nucleus of depressed patients. Neuroendocrinology 60: 436-444.

Raadsheer FC, van Heerikhuize JJ, Lucassen PJ, Hoogendijk WJ, Tilders FJ, Swaab DF (1995). Corticotropin-releasing hormone mRNA levels in the paraventricular nucleus of patients with 
Alzheimer's disease and depression. Am J Psychiatry 152 $1372-1376$

Rassnick S, Heinrichs SC, Britton KT, Koob GF (1993). Microinjection of a corticotropin releasing factor antagonist into the central nucleus of the amvgdala reverses anxiogenic-like effects of ethanol withdrawal. Brain Res 605: 25-32.

Rivest S, Leflamme N, Nappi RE (1995). Immune challenge and immobilization stress induce transcription of the gene encoding the CRF receptor in selective nuclei of the rat hypothalamus. J Neurosci 15: 2680-2695.

Rosenzweig MR, Bennett EL (1996). Psychobiology of plasticity: effects of training and experience on brain and behavior. Behav Brain Res 78: 57-65.

Sakura S, Hashimoto K, Bollen AW, Ciriales R, Drasner K (1996). Intrathecal catheterization in the rat: improved technique for morphologic analysis of drug-induced injury. Anesthesiology 85: 1184-1189.

Sanchez MM, Ladd CO, Plotsky PM (2001). Early adverse experience as a developmental risk factor for later psychopathology: evidence from rodent and primate models. Dev Psychopathol 13: 419-449.

Sanchez MM, Noble PM, Lyon CK, Plotsky PM, Davis M, Nemeroff $\mathrm{CB}$ et al (2005). Alterations in diurnal cortisol rhythm and acoustic startle response in nonhuman primates with adverse rearing. Biol Psychiatry 57: 373-381.

Sanchez MM, Young LJ, Plotsky PM, Insel TR (1999). Autoradiographic and in situ hybridization localization of CRF1 and CRF2 receptors in non-human primate brain. J Comp Neurol 408: 365-377.

Schmidt M, Oitzl MS, Levine S, de Kloet ER (2002). The HPA system during the postnatal development of CD1 mice and the effects of maternal deprivation. Brain Res Dev 139: 39-49.

Schulkin J, McEwen BS, Gold PW (1994). Allostasis, the amygdala and anticipatory angst. Neurosci Biobehav Rev 18: 1-12.

Sherman JE, Kalin NH (1988). ICV-CRH alters stress-induced freezing behavior without affecting pain sensitivity. Pharmacol Biochem Behav 30: 801-807.

Simmons DM, Arriza JL, Swanson LW (1989). A complete protocol for in situ hybridization of messenger RNAs in brain and other tissues with radiolabeled single-stranded RNA probes. $J$ Histotechnol 12: 169-181.

Sirinathsinghji DJS, Rees LH, Rivier J, Vale W (1983). Corticotropin-releasing factor is a potent inhibitor of sexual receptivity in the female rat. Nature 305: 230-235.

Smith EL, Batuman OA, Trost RC, Coplan JD, Rosenblum LA (2002). Transforming growth factor-beta 1 and cortisol in differentially reared primates. Brain Behav Immun 16: 140-149.

Stenzel-Poore MP, Heinrichs SC, Rivest S, Koob GF, Vale WW (1994). Overproduction of corticotropin-releasing factor in transgenie mice: a genetic model of anxiogenic behavior. $J$ Neurosci 14: 2579-2584.

Stern J (1997). Offspring-induced nurturance: animal-human parallels. Dev Psychobiol 31: 19-37.

Stout SC, Nemeroff CB (1994). Stress and psychiatric disorders. Semin Neurosci 6: 271-280.

Streckler T, Holsboer F (1999). Corticotropin-releasing hormone receptor subtypes and emotion. Biol Psychiatry 46: 1480-1508.
Suchecki D, Rosenfeld P, Levine S (1993). Maternal regulation of the hypothalamic-pituitary-adrenal axis in the infant rat: the role of feeding and stroking. Dev Brain Res 75: 192-195.

Sutton RE, Koob GF, Le Moal M, RivierJ, Vale W (1982). Corticotropin-releasing factor (CRF) produces behavioral activation in rats. Nature 297: 331-333.

Swerdlow NR, Gever MA, Vale WW, Koob GF (1986). Corticotropin releasing factor potentiates acoustic startle in rats: blockade by chlordiazepoxide. Psychopharmacology 88: 142-152.

Swiergiel AH, Takahashi LK, Kahn NH (1993). Attenuation of stress-induced by antagonism of corticotropin-releasing factor receptors in the central amygdala in the rat. Brain Res 623: 229-234.

Takahashi LK, Kalin NH, Vandenburgt JA, Sherman JE (1989). Corticotropin-releasing factor modulates defensive withdrawal and exploratory behavior in rats. Behav Neurosci 103: 648-654.

Thrivikraman KV, Nemeroff CB, Plotsky PM (2000). Sensitivity to glucocorticoid-mediated fast-feedback regulation of the hypothalamic-pituitary-adrenal axis is dependent upon stressor specific neurocircuitry. Brain Res 870: 87-101.

Thrivikraman KV, Plotsky PM (1993). Absence of glucocorticoid negative feedback to moderate hemorrhage in conscious rats. Am J Physiol 264: E497-E503.

Valentino RJ, Curtis AL, Page ME, Pavcovich LA, Florin-Lechner SM (1998). Activation of the locus cereulus brain noradrenergic system during stress: circuitry, consequences, and regulation. Adv Pharmacol 42: 781-784.

Valentino RJ, Foote SL (1988). Corticotropin-releasing hormone increases tonic but not sensory-evoked activity of noradrenergic locus coeruleus neurons in unanesthetized rats. J Neurosci 8: 1016-1025.

Van Bockstaele EJ, Bajic D, Proudfit H, Valentino RJ (2001). Topographic architecture of stress-related pathways targeting the noradrenergic locus coeruleus. Physiol Behav 73: 273-283.

van der Kar LD, Piechowski RA, Rittenhouse PA, Gray TS (1991). Amygdaloid lesions: differential effect on conditioned stress and immobilization-induced increases in corticosterone and renin secretion. Neuroendocrinology 54: 89-95.

Viau V, Sharma S, Plotsky PM, Meaney MJ (1993). The hypothalamic-pituitary-adrenal response to stress in handled and nonhandled rats: differences in stress-induced plasma ACTH secretion are not dependent upon increased corticosterone levels. J Neurosci 13: 1097-1105.

Weaver ICG, Cervoni N, Champagne FA, D’Alessio AC, Sharma S, Seckl JR et al (2004b). Epigenetic programming by maternal behavior. Nat Neurosci 8: 847-854.

Weaver ICG, Diorio D, Seckl JR, Dymov S, Meaney MJ (2004a). Early environmental regulation of hippocampal glucocorticoid receptor gene expression: characterization of intracellular mediators and potential genomic targets. Ann NY Acad Sci 1024: $182-212$.

Weiss EL, Longhurst JG, Mazure CM (1999). Childhood sexual abuse as a risk factor for depression in women: psychosocial and neurobiological correlates. Am J Psychiatry 156: 816-828.

Yaksh TL, Rudy T (1976). Chronic catheterization of the spinal subarachnoid space. Physiol Behav 17: 1031-1036. 